\title{
Case study of prioritisation of information communication technologies in family small medium enterprises - using the analytic hierarchy process
}

\section{Seyed Kaveh Jamali*}

Faculty of Management, Multimedia University (MMU), Malaysia

Email: jamali.kaveh@yahoo.com

*Corresponding author

\section{Behrang Samadi and Seyed Amirhossein Mousavi}

Faculty of Business,

Asia Pacific University of Technology and

Innovation (APU), Malaysia

Email: behrang@apu.edu.my

Email: amir_mousavi@hotmail.com

\section{Hamed Hakimian}

Graduate School of Management,

University Putra Malaysia (UPM), Malaysia

Email: hamedhakimian7@gmail.com

\begin{abstract}
This study limits the information communication technologies (ICTs) to the most appropriate one in the context of family small medium enterprises (SMEs), in terms of fulfilling their distinct needs and objectives. The purpose of the study is to explore the most appropriate ICT in family SMEs. In this way, the related ICTs used in the context of SMEs are evaluated based on the specific needs and objectives of family SMEs. The findings show that internet/website is the most appropriate ICT in family SMEs, particularly in Iran.
\end{abstract}

Keywords: family SMEs; information communication technology; ICT; analytic hierarchy process.

Reference to this paper should be made as follows: Jamali, S.K., Samadi, B., Mousavi, S.A. and Hakimian, H. (2020) 'Case study of prioritisation of information communication technologies in family small medium enterprises - using the analytic hierarchy process', Int. J. Family Business and Regional Development, Vol. 1, No. 1, pp.81-99.

Biographical notes: Seyed Kaveh Jamali is a $\mathrm{PhD}$ holder in IT Management and he have been honoured to participate in several related articles, mainly in ICT technology and innovation adoption. His body of interest is in a wide-ranged area; however, he think is probably closer to electronic business, 
SMEs organisational behaviour and project management. He had had several years of academic and industrial exposure in almost lecturing and managerial positions.

Behrang Samadi is currently a Senior Lecturer and Program Leader at Asia Pacific University of Technology and Innovation (APU). He has awarded his $\mathrm{PhD}$ from Multimedia University (MMU) in 2015. Briefly, he has more than seven years professional teaching and research experience at the university level and five years industrial experience. He has successfully published more than 20 research paper in index conferences and journals in the field of E-Commerce, Knowledge Management and Management Information System. $\mathrm{He}$ is currently a reviewer of few high index journals.

Seyed AmirHossein Mousavi particular area of expertise is in artificial intelligence, electronic commence and management. He obtained his BA (Hon.) degree in 2010 and from 2010 to 2012 he has finished his Master in Software Engineering at Staffordshire University. He has started his PhD studies in 2014 under the management department at Asia Pacific University of Technology and Management. His area of research is in the field of technology management.

Hamed Hakimian is currently a researcher in the fields of International Business, Business Intelligence, E-commerce, Information System and Recommendation Systems. He received his Bachelor's degree in Business Information System from Staffordshire University in 2015 and his Master of Business Administration in International Business from University Putra Malaysia in 2016.

\section{Introduction}

Adoption of ICT in SMEs could be a critical investment for significantly improving their competitiveness. In the new industrial growth paradigm, the need for growth and sustained competitiveness is particularly relevant to SMEs. Relatively, ICT could be a critical investment, not only as a competitive driver, but also as an integral part of the strategic plan with direct business-related benefits, such as efficiency enhancement, and operational savings, and indirect business-related benefits like internationalisation and market improvement. This, in turn, will guarantee the long-term survival alongside superior economy of scale and resource accessibility (Calabrò and Mussolino, 2013).

This might be even more considerable in family SMEs with their unique situation (i.e., unknown image, marketing infirmity). Family SMEs could benefit from ICTs in respect of their three main subsystems. They could potentially improve the cash flow and operational efficiency in terms of the business subsystem as well as improve the family image in the local market and provide better managerial control for CEOs as the other organisational subsystem in such distinct SMEs. In this respect, ICTs may make family SMEs more visible to the external environment, mirror their corporate social responsibility (CSR) to the socio-economic environment more clearly and facilitate better accessibility to the environment resources. This would not only create a good image for the company but also a good family name in the local community (Khin et al., 2015). A well-known family name may be perceived as a family asset providing future prosperity. 
In relation to CEO priorities, ICTs may also be perceived as a monitoring system in SMEs.

However, with regard to the typical conservatism (high fraction of assets provided by family wealth), determining the appropriate technology structure among ICTs seems to be vital. This has motivated this study to identify the most appropriate ICTs in family SMEs among those specified for SMEs - intranet, extranet, internet/website, EDI, EFT, email and Barcode - in the study of Alzougool and Kurnia (2008).

Nevertheless, they are still too varied in terms of business focus, initiating costs and/or maintenance, and technical/technological structure. Although EDI with its narrow focus is suited for communication with suppliers, the internet with its broader focus facilitates internet business-to-business and/or business-to-consumer (B2C) communication for SMEs in terms of both buying and selling. Consequently, identifying the most appropriate ICT for family SMEs is targeted in the current study ranked using the analytical hierarchy process (AHP). To this end, this study addresses the following issues:

a decomposition of family SMEs' short-term and strategic objectives

b narrowing down the relevant ICTs based on the decomposed objectives.

\subsection{The distinct needs and objectives of family SMEs}

The organisation value in Family SMEs reflects a combination of both family and business concerns. In particular, the main business objectives of family SMEs involve 'increasing the financial value of the business', 'growth of the sales figure of the business', 'maximisation of profit', and 'increasing the market share of the business'. The family goals in such distinct SMEs are mainly 'preservation of family control and independence', 'minimisation of family conflicts', and 'provision of work for family members' (Molly, 2009). For guaranteeing the success of family SMEs over generations in the new market, having a balanced family and business strategic orientation is critical (Idris et al., 2017).

\subsection{Family SMEs and ICTs in Iran}

Family SMEs comprise the majority of SMEs, and are the dominant form of the private sector in Iran (UNIDO, 2003). Family SMEs in Iran, where the socio-economic structure needs to utilise its main basic factors, play a substantial role in transforming a family to a business. They overcome the limited availability of organisational resources to run a business through 'intergenerational entrepreneurial cherishment', 'high national savings', and 'unemployment manpower' deployment, thus improving the growth of the private sector. They also suffer from an unknown image, marketing weakness, and correspondingly poor ICT usage, thereby hindering their preparation for globalised competition at this crucial time when Iran is planning to join the 'WTO'.

In Iran, there is a dearth of information concerning such SMEs, and they are simply classified by the overall categorisation of SMEs. Based on UNIDO 2003, as the last available related reference in Iran, Family SMEs are sub-divided into two main categories based on their activity: 
1 providing the general needs of consumers

2 intermediary goods and materials for large enterprises.

Referring to the Statistical Centre of Iran, as the latest available nationwide statistical data collection from businesses in Iran, more than $99 \%$ of all Iranian enterprises have less than 250 employees, and, hence, are categorised as SMEs, with the majority being family SMEs (UNIDO, 2003). Grounded on the definition of family SMEs, Iranian family SMEs as the population of interest in the current study are defined as private enterprises with a maximum of 249 employees and a minimum of two Iranian owner-managers who belong to the family owning the majority of the company's shares.

The rate of ICT adoption in such SMEs in Iran, despite their numerous advantages, and as a potential solution to their existing challenges, is still questionably low (Hajkarimi and Azizi, 2008). Such unwillingness might have roots in the selection of such technology structures, which are not well-suited for satisfying their distinct needs. On the other hand, they might be confused by the wide range of ICTs or hampered by their limited financial resources. Accordingly, in the current study, the most appropriate ICT for fulfilling the main needs of family SMEs is prioritised from the wide range of ICTs appropriate in SMEs, thereby overcoming the barrier of economic development (EC) deployment extension (Jamali et al., 2015).

Based on the literature review, the key strategic criteria were extracted from the literature pertaining to family SMEs. Referring to the related literature, the organisation value in family SMEs can be categorised as commercial concerns or non-commercial concerns. For commercial concerns, these involve 'increasing the financial value of the business', 'growth of the sales figure of the business', 'maximisation of profit', and 'increasing the market share of the business', while for non-commercial concerns 'preservation of family control and independence', 'minimisation of family conflicts', and 'provision of work for family members', are considered as the key criteria (Memili et al., 2013).

For identifying the consistent strategic objectives, an open questionnaire was completed by ten randomly selected members from chosen experts, to refine the elements of the hierarchical structure of the key main criteria in line with the strategic means objectives (extracted from the unstructured interviews and discussions by means of several online meetings with the selected experts). The highlighted consistent strategic objectives comprise:

1 minimisation of family conflicts

2 preservation of family independence

3 increasing market share

4 maximisation of profit

5 growth of sales

6 increasing the financial value of business, which were ranked out of ten by the other chosen experts, by means of a closed-question questionnaire. 
The seven and above-ranked items involving 'minimisation of family conflicts', 'preservation of family independence', 'increasing market share', 'maximisation of profit', and 'growth of sales', were identified as the final criteria for prioritising the most appropriate ICT in family SMEs.

\section{Literature review and framework}

In terms of the family SMEs' financial restrictions and specific needs/objectives, analytically identifying the most relevant technology to fit their needs and objectives is essential. To this end, the current study proposes a systematic framework to match the features of the ICTs with the objectives of the family SMEs, by identifying the appropriate attributes and setting up consistent evaluation criteria for facilitating a group decision process (Migdad et al., 2016).

In the literature, some methods were applied to evaluate ICTs, such as scoring, ranking, mathematical optimisation, and multi-criteria decision. Among them, the scoring method has several constraints and seems too simple to reflect the opinions of decision makers beyond doubt. However, the goal programming, 0-1 programming, and nonlinear programming could be applied to resource optimisation in the selection; for resource allocation optimisation a nonlinear programming model is needed.

Thus, such models may only partially address the selection process (Lee and Kim, 2000). To overcome these limitations, some studies in the literature have tried to combine the analytic network process (ANP) technique and $0-1$ goal-programming model. However, this might be too complicated for managers, particularly when the attributes are qualitative. Moreover, such methodologies focus on quantifiable calculations without a systematic approach for selection linked to the objectives of the firms.

Recently, the AHP has been widely used in the related literature for determining the priority of alternatives based on the importance of relative attributes in a multiple criteria decision-making problem. For example, Oztaysi (2014) carried out a study of the selection of content management systems (CMS) from among alternatives. The decision model was built based on the AHP consisting of seven criteria and four alternatives. However, they did not illustrate how they extracted the proper criteria for evaluating the fulfilment of the strategic goals.

In the current study, to fill the gap, a strategic means structure using a systematic AHP method approach for evaluating the ICTs in family SMEs is utilised. Accordingly, based on the key strategic criteria extracted from the literature pertaining to family SMEs, and identified by members of the first expert team who were closely connected to family SMEs in Iran (organised through a structured online meeting), the strategic means objectives and priorities of family SMEs were outlined. After the criteria had been identified, they were ordered in accordance with the opinions of the expert team based on their rank. Any duplicated, or redundant criteria were eliminated. Moreover, the criteria were carefully reviewed for final inclusion in the research model. Figure 1 depicts the research model based on the key selection criteria. 
Figure 1 Research model

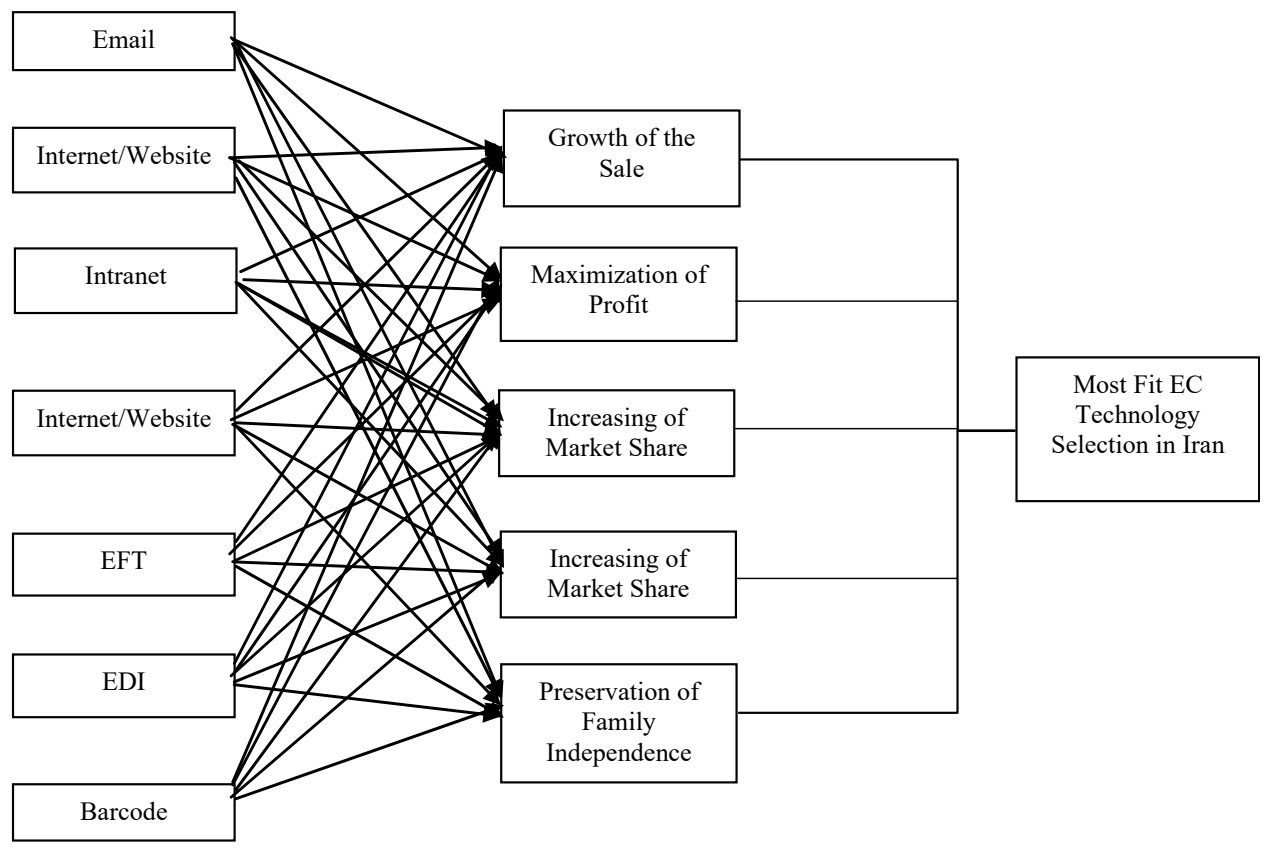

To finalise the ICT selection decision, a clear definition of the criteria in the model - 'minimisation of family conflicts', 'preservation of family independence', 'increasing market share', 'maximisation of profit', and 'growth of sales' were presented by the experts in sufficient detail (see Figure 2), by referring to the literature pertaining to family firms (i.e., Klein et al., 2005; Uhlaner, 2005; Uhlaner et al., 2007; Molly, 2009).

Figure 2 Criteria definition

\begin{tabular}{|c|c|}
\hline $\begin{array}{l}\text { Growth of the } \\
\text { sale }\end{array}$ & $\begin{array}{l}\text { Measure CEOs' satisfaction in Iranian family SMEs form sale } \\
\text { improvement by adopting an alternative EC technology }\end{array}$ \\
\hline $\begin{array}{l}\text { Maximisation } \\
\text { of profit }\end{array}$ & $\begin{array}{l}\text { Measure CEOs. Satisfaction in Iranian family SMEs form profit } \\
\text { improvement by adopting an alternative EC technology }\end{array}$ \\
\hline $\begin{array}{l}\text { Increasing of } \\
\text { market share }\end{array}$ & $\begin{array}{l}\text { Measure CEOs' satisfaction in Iranian family SMEs form market } \\
\text { share improvement by adopting an alternative EC technology }\end{array}$ \\
\hline $\begin{array}{l}\text { Presentation of } \\
\text { family } \\
\text { independence }\end{array}$ & $\begin{array}{l}\text { Measure CEOs' satisfaction in Iranian family SMEs form providing } \\
\text { the control assistance for family over the company }\end{array}$ \\
\hline $\begin{array}{l}\text { Minimisation of } \\
\text { family conflicts }\end{array}$ & $\begin{array}{l}\text { Measure CEOs' satisfaction in Iranian family SMEs form providing } \\
\text { the harmonic relationship among family in the company }\end{array}$ \\
\hline
\end{tabular}




\section{Research methodology}

In this step, a systematic blueprint for the current study to reach the main research objective - prioritising the most appropriate information communication technology adoption in family SMEs - was developed (see Figure 3). Accordingly, primary qualitative data were collected from the samples, purposely selected from the internal database of the Tadvin Co. From the 67 family SMEs in the database, only 27 were eligible as experts for the current study. Of these, 20 CEOs agreed to participate in this study, thanks to the persuasive influence of Tadvin Co. (Tadvin Co. is one of the top-ranked management consultancies in Iran, and is highly recognised as the previous branch of Ernst \& Young International Co. in Iran). The collected data were transformed to numeric data through AHP, for which comparative analysis was performed to rank the alternatives based on the outlined criteria. The needs and objectives extracted from the literature in such distinct SMEs were linked to the alternatives' features using a decomposed structuring method by eligible purposive selected know-how experts. Then a consistency assessment using the AHP method was employed for evaluation of the validity and reliability.

Figure 3 Research methodology

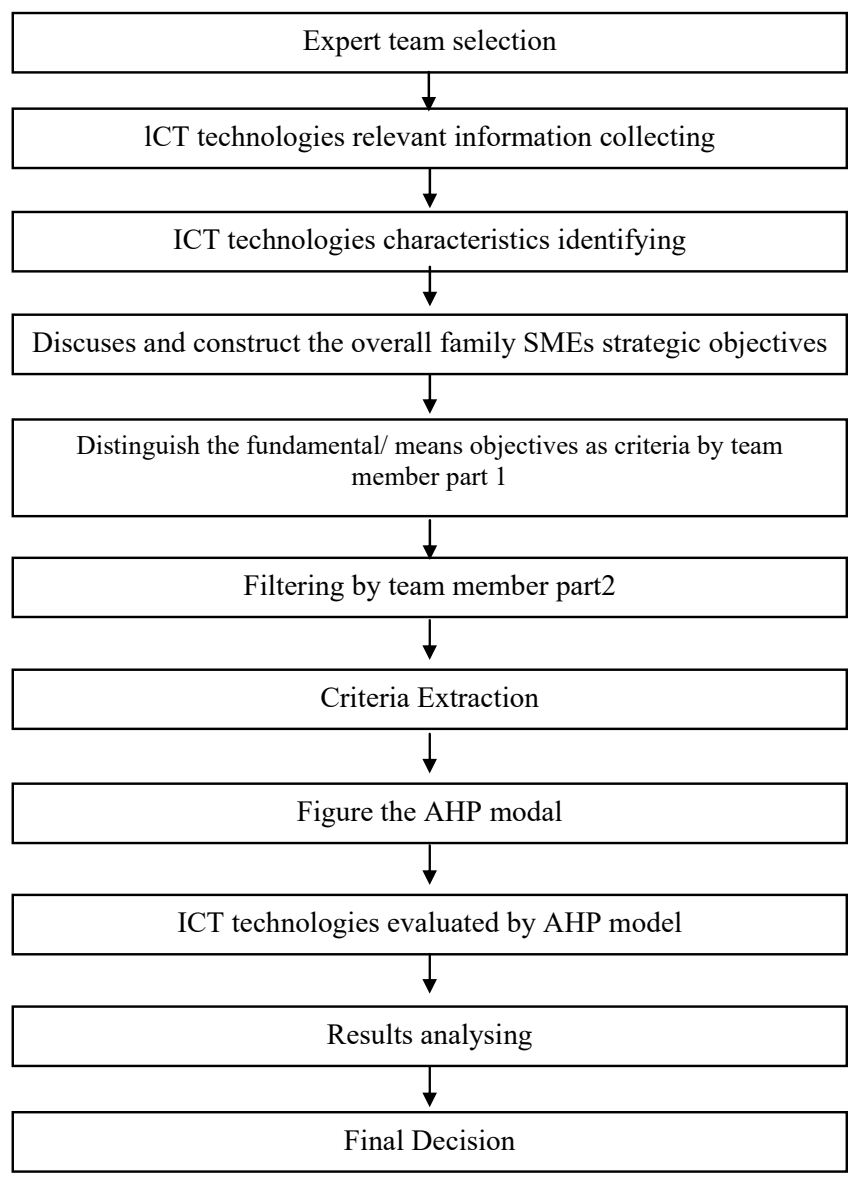




\subsection{Sample and data}

For the current study, an expert member (as an element) was defined as a CEO of a family SME with a minimum of five years work experience as a manager and a bachelor degree in a related field. Through the purposive sampling technique, samples were selected using the internal Tadvin co. database as the sampling frame, which resulted in the participation of 20 eligible experts. The unit of analysis was a family SME.

\subsection{Analysis}

To achieve the strategic means objectives, unstructured interviews and discussions through several online meetings with the selected experts was undertaken. Then, an open questionnaire was completed by ten randomly selected members from the chosen experts to refine the elements concerning the hierarchical structure of the strategic objectives, achieved by means of ICT alternatives in family SMEs. The consistent strategic objectives in line with the lower-level objectives of the adoption of alternatives in family SMEs were highlighted as follows:

1 minimisation of family conflicts

2 preservation of family independence

3 increasing market share

4 maximisation of profit

5 growth of sales

6 increasing the financial value of business.

The importance of the outcomes was ranked out of ten by the other chosen experts, by means of a closed-question questionnaire. The items with an average value of seven and more were retained for the final criteria. The ultimate goal "Selecting the most appropriate ICT in family SMEs" was processed by structuring a decomposition of strategic means objectives in which the strategic goals in family SMEs (extracted from the literature) were systematically linked to the features of the alternatives through lower-level objectives as latent criteria using the Delphi Technique, ranked out of score of ten. The items ranked seven and above were: 'minimisation of family conflicts', 'preservation of family independence', 'increasing market share', 'maximisation of profit', and 'growth of sales' and thereby constitute the final criteria for prioritising the most appropriate ICT in family SMEs (Table 1).

Table 1 Final criteria

\begin{tabular}{lccccccccccc}
\hline Member & 1 & 2 & 3 & 4 & 5 & 6 & 7 & 8 & 9 & 10 & $\bar{x}$ \\
\hline Minimisation of family conflict & 10 & 4 & 10 & 1 & 10 & 7 & 6 & 10 & 9 & 8 & 7.5 \\
Preservation of family independence & 6 & 3 & 9 & 8 & 8 & 10 & 7 & 9 & 8 & 6 & $7-4$ \\
Increasing of market share & 7 & 7 & 6 & 7 & 9 & 9 & 8 & 7 & 10 & 9 & 7.9 \\
Maximising of profit & 9 & 6 & 6 & 6 & 9 & 8 & 9 & 3 & 7 & 10 & 7.3 \\
Growth of sales & 8 & 10 & 7 & 9 & 8 & 8 & 7 & 4 & 6 & 4 & 7.1 \\
Increasing the financial value of business & 6 & 6 & 7 & 6 & 7 & 6 & 10 & 7 & 6 & 6 & 6.7 \\
\hline
\end{tabular}


The research model's hierarchy reflects the features of the ICTs that are suitable for the goals of family SMEs. To select the most appropriate ICT from the alternatives, the strategic means objectives (main and fundamental objectives) were consistently approached by participants as the criteria in the evaluation process.

To this end, five experts with the most work experience and highest educational level among the chosen experts completed the questionnaire set for the comparison of the paired alternatives for each of the attributes and inter-attribute relative importance, which was converted to a numerical 1-9 scale. The value of the viewpoint of five chosen members was assumed to be equal to the same coefficient. Then, the normalised principal Eigenvector, the so-called priority vector, was calculated (see Tables 2 and 3).

Table 2 Inter-attributes priority vector

\begin{tabular}{lcc}
\hline Rank & Criteria & Weight \\
\hline 1 & Minimisation of family conflicts & .308 \\
2 & Preservation of family independence & .256 \\
3 & Increasing of market share & .166 \\
4 & Growth of sales & .138 \\
5 & Maximisation of profit & .128 \\
\hline
\end{tabular}

Table 3 Alternatives priority vector

\begin{tabular}{lccccc}
\hline & $\begin{array}{c}\text { Minimisation } \\
\text { offamily } \\
\text { conflicts }\end{array}$ & $\begin{array}{c}\text { Preservation } \\
\text { offamily } \\
\text { independence }\end{array}$ & $\begin{array}{c}\text { Increasing } \\
\text { of market } \\
\text { share }\end{array}$ & $\begin{array}{c}\text { Growth } \\
\text { of sales }\end{array}$ & $\begin{array}{c}\text { Maximisation } \\
\text { of profit }\end{array}$ \\
\hline Email & 0.217 & 0.093 & 0.059 & 0.086 & 0.067 \\
Intranet & 0.064 & 0.060 & 0.125 & 0.100 & 0.033 \\
$\begin{array}{l}\text { Internet/V4Tebsite } \\
\text { Extranet }\end{array}$ & 0.454 & 0.407 & 0.244 & 0.203 & 0.365 \\
$\begin{array}{l}\text { Electronic data } \\
\text { interchange }\end{array}$ & 0.054 & 0.066 & 0.135 & 0.072 & 0.126 \\
$\begin{array}{l}\text { Electronic funds } \\
\text { transfer }\end{array}$ & 0.029 & 0.033 & 0.031 & 0.034 & 0.046 \\
Barcode & 0.042 & 0.191 & 0.044 & 0.335 & 0.229 \\
\hline
\end{tabular}

\subsection{Validity and reliability}

In this step, the validity and reliability of the study was determined by the consistency ratio among the paired comparisons. Accordingly, all the paired comparisons based on each of criteria were consistent. 


\subsubsection{Inter-attribute consistency}

$$
\begin{aligned}
& \lambda \max =\frac{5.32+5.39+5.24+4.78+5.70}{5}=5.28 \\
& (\mathrm{CI})=\frac{\lambda \max -n}{n-1}=\frac{5.28-5}{5-1}=.07 \\
& \mathrm{CR}=\frac{C I}{R I}(\text { five alternatives, thus RI was } 1.12) \\
& \mathrm{CR}=\frac{.07}{1.12}=.06<1
\end{aligned}
$$

\subsection{2 'Minimisation of family conflicts' consistency}

$\lambda \max =7.645038$

$$
\begin{aligned}
& (\mathrm{CI})=\frac{\lambda \max -n}{n-1}=\frac{7.645038-7}{7-1}=.1075 \\
& \mathrm{CR}=\frac{C I}{R I}=\frac{.1075}{1.32}=.081<0.1(\text { seven alternatives, thus RI was 1.32) }
\end{aligned}
$$

\subsection{3 'Preservation of family independence' consistency}

$\lambda \max =7.746931$

$$
\begin{aligned}
& (\mathrm{CI})=\frac{\lambda \max -n}{n-1}=\frac{7.6746931}{7-1}=.1244 \\
& \mathrm{CR}=\frac{C I}{R I}=\frac{.1244}{1.32}=0.094<0.1(\text { seven alternatives, thus RI was 1.32) }
\end{aligned}
$$

\subsection{4 'Increasing market share' consistency}

$\lambda \max =7.7641296$

$$
\begin{aligned}
& (\mathrm{CI})=\frac{\lambda \max -n}{n-1}=\frac{7.641296-7}{7-1}=0.1068 \\
& \mathrm{CR}=\frac{C I}{R I}=\frac{0.1068}{1.32}=0.809<0.1(\text { seven alternatives, thus RI was 1.32) }
\end{aligned}
$$

\subsection{5 'Maximisation of profit' consistency}

$\lambda \max =7.365355$

$(\mathrm{CI})=\frac{\lambda \max -n}{n-1}=\frac{7.365355-7}{7-1}=0.0608$

$\mathrm{CR}=\frac{C I}{R I}=\frac{0.0608}{1.32}=.0461<0.1$ (seven alternatives, thus RI was 1.32) 


\subsection{6 'Growth of sales' consistency}

$$
\begin{aligned}
& \lambda \max =7.4874 \\
& (\mathrm{CI})=\frac{\lambda \max -n}{n-1}=\frac{7.4874-7}{7-1}=0.0812 \\
& \mathrm{CR}=\frac{C I}{R I}=\frac{0.0812}{1.32}=.0615<0.1 \text { (seven alternatives, thus RI was 1.32) }
\end{aligned}
$$

As can be seen, the consistency index (CI) and consistency ratio (CR) of each decision maker's paired comparison matrix was less than the threshold value of 0.1 (Saaty, 1980), thereby ensuring the consistency of the decision maker in assigning the paired comparisons.

\subsection{Research findings}

Based on the ranking results for finalised alternatives depicted in Table 4, internet/website was found to the most appropriate ICT in family SMEs, particularly in Iran.

Table 4 Finalised alternatives' ranking

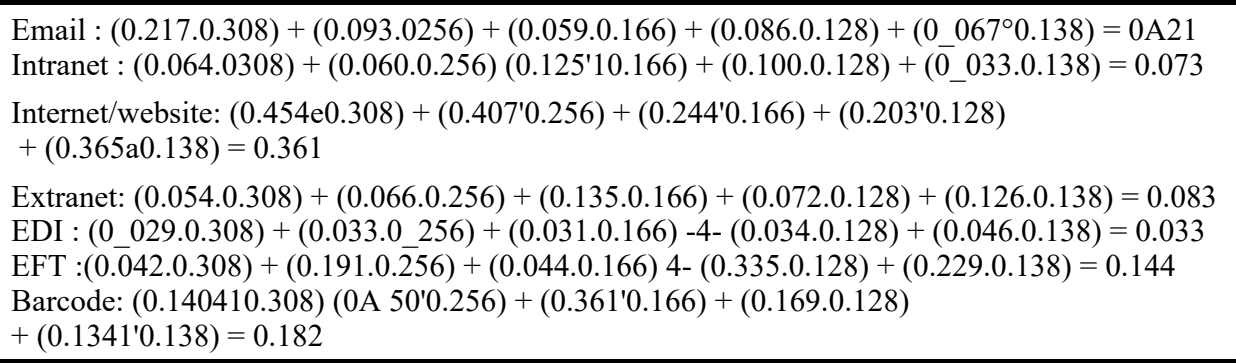

\section{Discussion}

This current research presented a comprehensive framework to identify the most appropriate ICT technology in family SMEs. The research model systematically linked the features of EC alternatives and the strategic objectives of family SMEs, pinned by the latent lower-level objectives in relation to ICT through consistent consideration based on a group decision process. Based on the finalised evaluation criteria, the alternatives were graded using the AHP in family SMEs. To avoid a constrained structure of objectives, the experts constructed a network of the fundamental objectives linked to the means objectives as the structure of strategic means objectives.

This study might be limited by the possible unseen layers in the structure of the objectives. Thus, an alternatives' ladder from the means objectives to the fundamental objectives as the latent criteria was used to attain a harmonised ICT selection process that was consistently modified by the decision makers. Therefore, generalisation of the research findings is limited with regard to the awareness, knowledge, and even cognitive bias of the participants. Moreover, the results may also be subject to limitation for 
generalisation, since the policy initiatives in family SMEs may differ from country to country.

To control the incongruity in the semantic imageries in the comparison evaluations, the AHP method was explained in depth to enable the participants to enhance their judging expertise. During the process, all-over consistency was ensured through asking the rationale for the decisions made by participants. Setting up the framework of the objectives increased the reliability of the results and avoided the adjustment of decisions.

\section{Conclusions}

In this study, an all-inclusive framework for selecting the most appropriate ICT in family SMEs was developed. The model proposed the essentials for selecting the appropriate ICT as a ladder, thereby linking the means objective networks to the fundamental objectives of family SMEs. The study contributes to the knowledge by developing a comprehensive ICT selection framework with the subsequent advantages:

a recognising the structure of the objectives with a certain consistency in family SMEs

b decomposing the complexity of the ICTs into easier attributes

c accelerating the agreement among participants

$\mathrm{d}$ assessing the features of the alternatives based on the distinct objectives in family SMEs.

This study contributes to theory by clearly illustrating how the proper criteria were selected for evaluating the fulfilment of the strategic goals, providing a strategic means structure for evaluating the ICTs in family SMEs depicted using a systematically AHP method approach.

The study contributes to practice through empirical identification of the specific ICT to be adopted in Iranian family SMEs as a distinct business type in terms of their unique business needs, such as growth and internationalisation; and family needs, such as family's image as well as the specific conditions in Iran as a developing country, such as the cultural (i.e., high uncertainty, avoidance), legal (i.e., high company tax rates without discrimination), infrastructure (i.e., 'less-impacted' domestic market), economics (i.e., deciding to join the 'WTO'), and political (i.e., undertaking a wide-ranging filtering policy related to cyber war concerns) aspects in Iran. In doing so, it provides clearer information to rearrange the resources in Iranian EC developing agencies, such as the Business Advisory Services (BAS), Business Innovation Centres (BIC), Training Centres, Business Associations and Incub Centres (Innovation centres) more competently to boost EC adoption in these Iranian SMEs.

As per the evaluation process, the consistency index $(\mathrm{CI})$ and consistency ratio (CR) of each paired comparison matrix was under the threshold value of 0.1 (Saaty, 1980) to ensure the consistency of the assigned paired comparisons, to avoid the need for reconsideration of the evaluations. Based on the results, the participants were properly consistent in ranking the alternative attributes in relation to the criteria, and 'internet/website' was found to be the most appropriate ICT in family SMEs in Iran. The result is in line with the study of Ajdari (2007), in which the internet/website was accredited as being the main growth driver of such SMEs in Iran. The finding is 
practically significant for such distinct SMEs to invest in the most suitable and proper ICT to overcome their challenges regarding their limited financial resources, which are highly dependent on of family assets.

\section{References}

Ajdari, B. (2007) Impact of e-commerce on internationalization of Iranian's SMEs, Thesis, Luleå University of Technology, Department of Business Administration and Social Sciences.

Alzougool, B. and Kurnia, S. (2008) 'ICTs adoption by SMEs: a conceptual study', 19th Australasian Conference on Information Systems, Christchurch, New Zealand.

Calabrò, A. and Mussolino, D. (2013) 'How do boards of directors contribute to family SME export intensity? The role of formal and informal governance mechanisms', Journal of Management \& Governance, Vol. 17, No. 2, pp.363-403.

Hajkarimi, A. and Azizi, S. (2008) 'Model of factors affecting e-commerce adoption in small businesses', Iranian Journal of Trade Studies (IJTS), Fall, Vol. 12, No. 48, pp.191-229.

Idris, A., Edwards, H. and McDonald, S. (2017) 'E-commerce readiness of SMEs in developing countires: a model-driven systematic literature review', UKAIS 2017:22nd Annual Conference, 3-5 April, St Catherine's College, Oxford, UK.

Jamali, S.K., Marthandan, G., Khazaei, M., Samadi, B. and Fie, D.Y.G. (2015) 'Conceptualizing model of factors influencing electronic commerce adoption in Iranian family SMEs', Asian Social Science, Vol. 11, No. 10, p.256.

Khin, E.W.S., Loong, C.K. and Singh, G. (2015) 'Credit control management and business performance: the Malaysian family SME perspective', The South East Asian Journal of Management, Vol. 9, No. 1, p.21.

Klein, S., Astrachan, J. and Smyrnios, K. (2005) 'The F-Pec scale of family influence: construction, validation, and further implication for theory', Entrepreneurship Theory and Practice, Vol. 29, No. 3, pp.321-339.

Lee, J. and Kim, S. (2000) 'Using analytic network process and goal programming for interdependent information system project selection', Computers \& Operations Research, Vol. 27, No. 4, p.89, pp.367-382, pp.380-399.

Memili, E., Misra, K., Chang, E.P. and Chrisman, J.J. (2013) 'The propensity to use incentive compensation for non-family managers in SME family firms', Journal of family business Management, Vol. 3, No. 1, pp.62-80.

Migdadi, M.M., Abu Zaid, M.K.S., Al-Hujran, O.S. and Aloudat, A.M. (2016) 'An empirical assessment of the antecedents of electronic-business implementation and the resulting organizational performance', Internet Research, Vol. 26, No. 3, pp.661-688.

Molly, V. (2009) The Heterogeneity of the Family Business: Goal Orientation, Intergenerational Differences and Succession, Doctoral dissertation, Antwerpen University, Belgium.

Oztaysi, B. (2014) 'A decision model for information technology selection using AHP integrated TOPSIS-Grey: the case of content management systems', Knowledge-Based Systems, Vol. 70, pp.44-54 [online] http://www.sciencedirect.com/science/article/pii/S0950705114000598.

Saaty, T. (1980) The Analytic Hierarchy Process, McGraw- Hill, New York.

Uhlaner, L. (2005) 'The use of the Guttman scale in development of a family orientation index for small-to-medium-sized firms', Family Business Review, Vol. 43, No. 1, pp.41-56.

Uhlaner, L., Tan, S. and Meijaard, J. (2007) 'Family orientation, strategic orientation and innovation performance in SMEs: a test of lagged effects', In Proceedings of the second European Conference on Entrepreneurship and Innovation, pp.201-210.

UNIDO (2003) Strategy document to enhance the contribution of an Efficient and Competitive Small and Medium sized Enterprises Sector to Industrial and Economic Development in the Islamic Republic of Iran, United Nations Industrial Development Organizations, Vienna. 


\section{Appendix 1}

\section{Integrated tables}

Table A1 Overall integrated table

\begin{tabular}{lccccc}
\hline & $\begin{array}{c}\text { Minimisation } \\
\text { of family } \\
\text { conflicts }\end{array}$ & $\begin{array}{c}\text { Preservation } \\
\text { of family } \\
\text { independence }\end{array}$ & $\begin{array}{c}\text { Increasing } \\
\text { of market } \\
\text { share }\end{array}$ & $\begin{array}{c}\text { Maximisation } \\
\text { of profit }\end{array}$ & $\begin{array}{c}\text { Growth of } \\
\text { sales }\end{array}$ \\
\hline $\begin{array}{l}\text { Minimisation of family } \\
\text { conflicts }\end{array}$ & 1 & 1.78 & 2.31 & 2.49 & 134 \\
$\begin{array}{l}\text { Preservation of family } \\
\text { independence }\end{array}$ & .56 & 1 & 2.16 & 2.7 & 1.74 \\
$\begin{array}{l}\text { Increasing of market share } \\
\text { Maximisation of profit }\end{array}$ & .43 & .46 & 1 & 1.14 & 2.35 \\
$\begin{array}{l}\text { Growth of sales } \\
\sum \bar{R} i j\end{array}$ & .74 & .37 & .87 & 1 & 1.31 \\
& 3.13 & 4.18 & 6.72 & 8.5 & 7.74 \\
\hline
\end{tabular}

Table A2 Integrated table based on minimisation of family conflicts criterion

\begin{tabular}{lccccccc}
\hline $\begin{array}{l}\text { Based on the } \\
\text { minimisation of family } \\
\text { conflicts criterion }\end{array}$ & Email & Intranet & $\begin{array}{c}\text { Internet/ } \\
\text { website }\end{array}$ & Extranet & $\begin{array}{c}\text { Electronic } \\
\text { data } \\
\text { interchange }\end{array}$ & $\begin{array}{c}\text { Electronic } \\
\text { funds } \\
\text { transfer }\end{array}$ & Barcode \\
\hline Email & 1 & 6.153 & .308 & 3.565 & 5.185 & 5.185 & 3.727 \\
Intranet & .162 & 1 & .116 & 2.297 & 2.297 & 2.168 & .284 \\
Internet/website & 3.245 & 8.585 & 1 & 8.359 & 8.558 & 8.79 & 6.971 \\
Extranet & .28 & .435 & .119 & 1 & 2.168 & 2.352 & .218 \\
$\begin{array}{l}\text { Electronic data } \\
\text { interchange }\end{array}$ & .192 & .435 & .116 & .461 & 1 & .37 & 174 \\
Electronic funds transfer & .192 & .461 & .113 & .402 & 2.701 & 1 & .231 \\
Barcode & .242 & 3.519 & .143 & 4.573 & 5.729 & 4.317 & 1 \\
$\sum \bar{R} i j$ & 5.313 & 20.588 & 1.915 & 20.657 & 27.638 & 24.182 & 12.605 \\
\hline
\end{tabular}

Table A3 Integrated tables based on the preservation of family independence criterion

\begin{tabular}{lccccccc}
\hline $\begin{array}{l}\text { Based on the } \\
\text { preservation of family } \\
\text { independence criterion }\end{array}$ & Email & Intranet & $\begin{array}{c}\text { Internet/ } \\
\text { website }\end{array}$ & Extranet & $\begin{array}{c}\text { Electronic } \\
\text { data } \\
\text { interchange }\end{array}$ & $\begin{array}{c}\text { Electronic } \\
\text { funds } \\
\text { transfer }\end{array}$ & Barcode \\
\hline Email & 1 & 2.766 & .191 & 2.701 & 2.491 & .268 & .425 \\
Intranet & .37 & 1 & .165 & .401 & 3.063 & .461 & .425 \\
Internet/website & 5.231 & 6.049 & 1 & 6.153 & 6.787 & 4.182 & 3.807 \\
Extranet & .37 & 2.491 & .162 & 1 & 2.766 & .218 & .213 \\
$\begin{array}{l}\text { Electronic data } \\
\text { interchange }\end{array}$ & .401 & .326 & .147 & .361 & 1 & .241 & .201 \\
Electronic funds transfer & 3.727 & 2.168 & .239 & 4.573 & 4.128 & 1 & 2.352 \\
Barcode & 2.352 & 2.352 & .262 & 4.682 & 4.959 & .425 & 1 \\
$\sum \bar{R} i j$ & 13.451 & 17.152 & 2.166 & 19.871 & 25.194 & 6.796 & 8.423 \\
\hline
\end{tabular}


Table A4 Integrated tables based on the improving operations quality and efficiency

\begin{tabular}{lccccccc}
\hline $\begin{array}{l}\text { Based on the improving } \\
\text { operations quality and } \\
\text { efficiency criterion }\end{array}$ & Email & Intranet & $\begin{array}{c}\text { Internet/ } \\
\text { website }\end{array}$ & Extranet $\begin{array}{c}\text { Electronic } \\
\text { data } \\
\text { interchange }\end{array}$ & $\begin{array}{c}\text { Electronic } \\
\text { funds } \\
\text { transfer }\end{array}$ & Barcode \\
\hline Email & 1 & .268 & .233 & .235 & 3.103 & 2.168 & .168 \\
Intranet & 3.727 & 1 & .326 & .361 & 4.959 & 5.185 & .264 \\
Internet/website & 4.282 & 3.063 & 1 & 3.365 & 6.92 & 6.381 & .341 \\
Extranet & 1948 & 2.766 & .297 & 1 & 2.93 & 2.766 & .275 \\
$\begin{array}{l}\text { Electronic data } \\
\text { interchange }\end{array}$ & .322 & .201 & .144 & .341 & 1 & .361 & .148 \\
Electronic funds transfer & .461 & .192 & .156 & .361 & 2.766 & 1 & .139 \\
Barcode & 5.966 & 3.776 & 2.93 & 3.189 & 6.721 & 7.159 & 1 \\
$\sum \bar{R} i j$ & 19.742 & 11.266 & 5.086 & 8.852 & 28.399 & 25.02 & 2.335 \\
\hline
\end{tabular}

Table A5 Integrated tables bases on the maximisation of profit

\begin{tabular}{lccccccc}
\hline $\begin{array}{l}\text { Based on the } \\
\text { maximisation of profit } \\
\text { criterion }\end{array}$ & Email & Intranet & $\begin{array}{c}\text { Internet/ } \\
\text { website }\end{array}$ & Extranet & $\begin{array}{c}\text { Electronic } \\
\text { data } \\
\text { interchange }\end{array}$ & $\begin{array}{c}\text { Electronic } \\
\text { funds } \\
\text { transfer }\end{array}$ & Barcode \\
\hline Email & 1 & .401 & .268 & 2.352 & 3.222 & .28 & .392 \\
Intranet & 2.491 & 1 & 314 & 2.491 & 2.282 & .228 & .284 \\
Internet/website & 3.727 & 3.177 & 1 & 2.766 & 5.546 & .435 & .93 \\
Extranet & .425 & .401 & .361 & 1 & 3.177 & .341 & .322 \\
$\begin{array}{l}\text { Electronic data } \\
\text { interchange }\end{array}$ & .3 & .361 & .18 & .314 & 1 & 161 & .223 \\
$\begin{array}{l}\text { Electronic funds transfer } \\
\text { Barcode }\end{array}$ & 3.565 & 4.373 & 2.297 & 2.93 & 6.181 & 1 & 2.93 \\
$\sum \bar{R} i j$ & 2.55 & 3.519 & .341 & 3.103 & 4477 & .341 & 1 \\
\hline
\end{tabular}

Table A6 Integrated tables based on the growth of sales

\begin{tabular}{lcccccccc}
\hline $\begin{array}{l}\text { Based on the growth of } \\
\text { sales criterion }\end{array}$ & Email & Intranet & $\begin{array}{c}\text { Internet/ } \\
\text { website }\end{array}$ & Extranet & $\begin{array}{c}\text { Electronic } \\
\text { data } \\
\text { interchange }\end{array}$ & $\begin{array}{c}\text { Electronic } \\
\text { funds } \\
\text { transfer }\end{array}$ & Barcode \\
\hline Email & 1 & 2.491 & .181 & .322 & 2.861 & .185 & .435 \\
Intranet & .401 & 1 & .169 & .185 & .392 & .161 & .314 \\
Internet/website & 5.501 & 5.908 & 1 & 3.177 & 6.71 & 2.352 & 4.891 \\
Extranet & 3.103 & 5.378 & .314 & 1 & 3.177 & .461 & .401 \\
Electronic data & .349 & 2.55 & .149 & .314 & 1 & .209 & .244 \\
interchange & & & & & & & \\
Electronic funds transfer & 5.378 & 6.187 & .425 & 2.168 & 4.781 & 1 & 2.491 \\
Barcode & 2.297 & 3.177 & .204 & 2.491 & 3.641 & .401 & 1 \\
$\sum \bar{R} i j$ & 18.029 & 26.682 & 2.442 & 9.657 & 22.562 & 4.769 & 9.776 \\
\hline
\end{tabular}




\section{Appendix 2}

\section{Normalised tables}

Table A7 Normalised table based on the Minimization of family conflicts criterion

\begin{tabular}{|c|c|c|c|c|c|c|c|c|}
\hline $\begin{array}{l}\text { Based on the } \\
\text { minimisation of } \\
\text { family conflicts } \\
\text { criterion }\end{array}$ & Email & Intranet & $\begin{array}{l}\text { Internet/ } \\
\text { website }\end{array}$ & Extranet & $\begin{array}{l}\text { Electronic } \\
\quad \text { data } \\
\text { interchange }\end{array}$ & $\begin{array}{c}\text { Electronic } \\
\text { funds } \\
\text { transfer }\end{array}$ & Barcode & $\rtimes$ \\
\hline Email & 0.188 & 0.299 & 0.161 & 0.173 & 0.188 & 0.214 & 0.296 & 0.217 \\
\hline Intranet & 0.030 & 0.049 & 0.061 & 0.111 & 0.083 & 0.090 & 0.023 & 0.064 \\
\hline Internet/website & 0.611 & 0.417 & 0.522 & 0.405 & 0.310 & 0.363 & 0.553 & 0.454 \\
\hline Extranet & 0.053 & 0.021 & 0.062 & 0.048 & 0.078 & 0.097 & 0.017 & 0.054 \\
\hline $\begin{array}{l}\text { Electronic data } \\
\text { interchange }\end{array}$ & 0.036 & 0.021 & 0.061 & 0.022 & 0.036 & 0.015 & 0.014 & 0.029 \\
\hline $\begin{array}{l}\text { Electronic } \\
\text { funds transfer }\end{array}$ & 0.036 & 0.022 & 0.059 & 0.019 & 0.098 & 0.041 & 0.018 & 0.042 \\
\hline Barcode & 0.046 & 0.171 & 0.075 & 0.221 & 0.207 & 0.179 & 0.079 & 0.140 \\
\hline
\end{tabular}

Table A8 Overall normalised table

\begin{tabular}{|c|c|c|c|c|c|c|c|c|c|}
\hline & & \multicolumn{2}{|c|}{$\begin{array}{c}\text { Minimisation } \\
\text { of family } \\
\text { conflicts }\end{array}$} & \multicolumn{2}{|c|}{$\begin{array}{l}\text { Preservation } \\
\text { of family } \\
\text { independence }\end{array}$} & $\begin{array}{c}\text { Increasing } \\
\text { of market } \\
\text { share }\end{array}$ & $\begin{array}{c}\text { Maximisation } \\
\text { of profit }\end{array}$ & $\begin{array}{l}\text { Growth } \\
\text { of sales }\end{array}$ & $\succsim$ \\
\hline \multicolumn{2}{|c|}{$\begin{array}{l}\text { Minimisation of family } \\
\text { conflicts }\end{array}$} & \multicolumn{2}{|c|}{31} & & .42 & .34 & .29 & .17 & .308 \\
\hline \multicolumn{2}{|c|}{$\begin{array}{l}\text { Preservation of family } \\
\text { independence }\end{array}$} & \multicolumn{2}{|c|}{18} & & .24 & .32 & .32 & .22 & .256 \\
\hline \multicolumn{2}{|c|}{$\begin{array}{l}\text { Increasing of market } \\
\text { share }\end{array}$} & \multicolumn{3}{|c|}{.14} & .11 & .15 & .13 & .30 & .166 \\
\hline Maximisation of & profit & \multicolumn{3}{|c|}{.13} & .09 & .13 & .12 & .17 & .128 \\
\hline Growth of sales & & \multicolumn{3}{|c|}{.23} & .13 & .06 & .14 & .13 & .138 \\
\hline \multicolumn{10}{|l|}{ Table A9 } \\
\hline $\begin{array}{l}\text { Based on the } \\
\text { preservation of } \\
\text { family } \\
\text { independence } \\
\text { criterion }\end{array}$ & Email & Intranet & $\begin{array}{l}\text { Inter } \\
\text { webs }\end{array}$ & & Extranet & $\begin{array}{l}\text { Electronic } \\
\quad \text { data } \\
\text { interchange }\end{array}$ & $\begin{array}{l}\text { Electronic } \\
\text { funds } \\
\text { transfer }\end{array}$ & Barcode & $\succsim$ \\
\hline Email & 0.074 & 0.161 & 0.08 & & 0.136 & 0.099 & 0.039 & 0.050 & $0-093$ \\
\hline Intranet & 0.028 & 0.058 & $0.0^{\circ}$ & & 0.020 & 0.122 & 0.068 & 0.050 & 0.060 \\
\hline Internet/website & 0.389 & 0.353 & 0.4 & & 0.310 & 0.269 & 0.615 & 0.452 & 0.407 \\
\hline Extranet & 0.028 & 0.145 & $0.0^{\circ}$ & & 0.050 & 0.110 & 0.032 & 0.025 & 0.066 \\
\hline $\begin{array}{l}\text { Electronic data } \\
\text { interchange }\end{array}$ & 0.030 & 0.019 & 0.0 & & 0.018 & 0.040 & 0.036 & 0.024 & 0.033 \\
\hline $\begin{array}{l}\text { Electronic } \\
\text { funds transfer }\end{array}$ & 0.277 & 0.126 & 0.1 & & 0.230 & 0.164 & 0.147 & 0.279 & 0.191 \\
\hline Barcode & 0.175 & 0.137 & 0.12 & & 0.236 & 0.197 & 0.063 & 0.119 & 0.150 \\
\hline
\end{tabular}


Table A10 Normalised tables based on the Increasing of market share criterion

\begin{tabular}{|c|c|c|c|c|c|c|c|c|}
\hline $\begin{array}{l}\text { Based on the } \\
\text { increasing of } \\
\text { market share } \\
\text { criterion }\end{array}$ & Email & Intranet & $\begin{array}{l}\text { Internet/ } \\
\text { website }\end{array}$ & Extranet & $\begin{array}{l}\text { Electronic } \\
\quad \text { data } \\
\text { interchange }\end{array}$ & $\begin{array}{l}\text { Electronic } \\
\text { funds } \\
\text { transfer }\end{array}$ & Barcode & 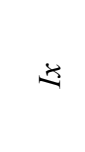 \\
\hline Email & 0.051 & 0.024 & 0.046 & 0.027 & 0109 & 0.087 & 0072 & 0.059 \\
\hline Intranet & 0.189 & 0.089 & 0.064 & 0.041 & 0.175 & 0.207 & 0.113 & 0.125 \\
\hline Intranet/website & 0.217 & 0.272 & 0.197 & $0.3 \mathrm{~S} 0$ & 0.244 & 0.255 & 0.146 & 0.244 \\
\hline Extranet & 0200 & 0.246 & 0.058 & 0113 & 0,103 & 0.111 & 0118 & 0.135 \\
\hline $\begin{array}{l}\text { Electronic data } \\
\text { interchange }\end{array}$ & 0016 & 0.018 & 0.028 & 0.039 & 0.035 & 0.014 & 0063 & 0031 \\
\hline $\begin{array}{l}\text { Electronic } \\
\text { funds transfer }\end{array}$ & 0.023 & 0.017 & 0.031 & 0.041 & 0.097 & 0040 & 0060 & 0044 \\
\hline Barcode & 0.302 & 0.335 & 0.576 & 0.360 & 0.237 & 0.286 & 0.428 & 0.361 \\
\hline
\end{tabular}

Table A11 Normalised tables based on the maximisation of profit criterion

\begin{tabular}{|c|c|c|c|c|c|c|c|c|}
\hline $\begin{array}{l}\text { Based on the } \\
\text { maximisation of } \\
\text { profit criterion }\end{array}$ & Email & Intranet & $\begin{array}{l}\text { Internet/ } \\
\text { website }\end{array}$ & Extranet & $\begin{array}{l}\text { Electronic } \\
\text { data } \\
\text { interchange }\end{array}$ & $\begin{array}{l}\text { Electronic } \\
\text { funds } \\
\text { transfer }\end{array}$ & Barcode & 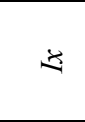 \\
\hline Email & 0.071 & 0030 & 0056 & 0,157 & 0.124 & 0.101 & 0.064 & 0.086 \\
\hline Intranet & 0.177 & 0.076 & 0.066 & 0.167 & 0.088 & 0.082 & 0.047 & 0.100 \\
\hline Internet/website & 0.265 & 0.240 & 0.210 & 0.185 & 0.214 & 0.156 & 0.153 & 0.203 \\
\hline Extranet & 0.030 & 0.030 & 0076 & 0.067 & 0.123 & 0.122 & 0.053 & 0.072 \\
\hline $\begin{array}{l}\text { Electronic data } \\
\text { interchange }\end{array}$ & 0.021 & 0027 & 0.035 & 0021 & 0039 & 0.058 & 0.037 & 0.034 \\
\hline $\begin{array}{l}\text { Electronic } \\
\text { funds transfer }\end{array}$ & 0.254 & 0.330 & 0.482 & $0.1 \%$ & 0.239 & 0.359 & 0.482 & 0.335 \\
\hline Barcode & 0151 & 0266 & $00^{\prime} 2$ & 0.207 & 0173 & 0122 & 0164 & 0169 \\
\hline
\end{tabular}

\section{Appendix 3}

\section{Priority vectors tables}

Table A12 Priority vectors table criteria

\begin{tabular}{lc}
\hline Criteria & Weight \\
\hline Minimisation of family conflicts & .308 \\
Preservation of family independence & .256 \\
Increasing of market share & .166 \\
Maximisation of profit & .128 \\
Growth of sales & .138 \\
\hline
\end{tabular}


Table A13 Priority vectors table alternatives based on the minimisation of family conflicts criterion

\begin{tabular}{lc}
\hline Alternatives based on the minimisation of family conflicts criterion & Weight \\
\hline Email & 0.217 \\
Intranet & 0.064 \\
Internet/website & 0.454 \\
Extranet & 0.054 \\
Electronic data interchange (EDI) & 0.029 \\
Electronic funds transfer (EFT) & 0.042 \\
Barcode & 0.140 \\
\hline
\end{tabular}

Table A14 Priority vectors table alternatives based on the preservation of family independence criterion

\begin{tabular}{lc}
\hline Alternatives based on the preservation of family independence criterion & Weight \\
\hline Email & 0.093 \\
Intranet & 0.060 \\
Internet/website & 0.407 \\
Extranet & 0.066 \\
Electronic data interchange (EDI) & 0.033 \\
Electronic funds transfer (EFT) & 0.191 \\
Barcode & 0.150 \\
\hline
\end{tabular}

Table A15 Priority vectors table alternatives based on the increasing of market share criterion

\begin{tabular}{lc}
\hline Alternatives based on the increasing of market share criterion & Weight \\
\hline Email & 0.059 \\
Intranet & 0.125 \\
Internet website & 0.244 \\
Extranet & 0.135 \\
Electronic data interchange (EDI) & 0.031 \\
Electronic funds transfer (EFT) & 0.044 \\
Barcode & 0.361 \\
\hline
\end{tabular}

Table A16 Priority vectors table alternatives based on the maximisation of profit criterion

\begin{tabular}{lc}
\hline Alternatives based on the maximisation of profit criterion & Weight \\
\hline Email & 0.086 \\
Intranet & 0.100 \\
Internet/website & 0.203 \\
Extranet & 0.072 \\
Electronic data interchange (EDI) & 0.034 \\
Electronic funds transfer (EFT) & 0.335 \\
Barcode & 0.169 \\
\hline
\end{tabular}


Table A17 Priority vectors table alternatives based on the growth of sales criterion

\begin{tabular}{lc}
\hline Alternatives based on the growth of sales criterion & Weight \\
\hline Email & 0.067 \\
Intranet & 0.033 \\
Internet website & 0.365 \\
Extranet & 0.126 \\
Electronic data interchange (EDI) & 0.046 \\
Electronic funds transfer (EFT) & 0.229 \\
Barcode & 0.134 \\
\hline
\end{tabular}

